\title{
IN WHO'S INTEREST? \\ LEVIRAT AND SORORAT MARRIAGES IN SOUTHEASTERN TURKEY ${ }^{1}$
}

\author{
AYSAN SEV'ER ${ }^{2}$ \\ University of Toronto at Scarborough \\ MAZHAR BAĞLI \\ Dicle University
}

\begin{abstract}
Sororat refers to a man's marriage to his deceased wife's sister, and levirat refers to a woman's marriage to her brother-in-law after the death of her husband. This article explores the gendered reactions to tensions and role confusion in these marriages. Forty-five people who were either currently living, or have recently lived in levirat and sororat marriages were interviewed. We observed that family and kin seem to be equally persistent on formulating levirat or sororat types of marriages for widows and widowers. However, men had an ultimate veto power over these arrangements and women did not. Moreover, tensions on women, especially in terms of establishing sexual intimacy with their new partners were traumatic. We argue that material considerations play a primary role on the continuation of these marriages, despite the problems these marriages entail, especially for women.
\end{abstract}

Functionalist orientations define the family in terms of its structures and its functions. Within the structural aspects, what is often emphasized is the presence of a heterosexual union, often with or expecting to have children and sharing the same residence. Blood or marriage ties amongst family members are assumed, and the intactness of

\footnotetext{
1 This research is supported by funds provided by the Social Sciences and Humanities Research Council of Canada (SSHRC) and by The Research Coordinator of Dicle University, Diyarbakir, Turkey. We thank the 45 respondents who candidly talked to us about their Levirat and Sororat marriages.

2 Department of Sociology, University of Toronto at Scarborough, 1265 Military Trail, Scarborough, ON, Canada, M1C 1A4, Phone, 416-287-7296, Fax: 416-287-6283.sever@utsc.utoronto.ca
} 
the families and their permanence are the preferred configurations (Eschleman \& Wilson, 2001; Kilbride, 1994; Parsons \& Bales, 1995; Ramu, 1993; Zelditch, 1955). In the west, the "intactness of the family" almost exclusively, refers to the nuclear family, which consists of the marital pair and their dependent children. In the developing world, "intactness of the family" may subsume larger family units that are considered indivisible, such as patriarchal family households with more than two generations of families that live within them. Some of these families may be polygynous or consist of closekin marriages (Elmaci, 1996). Functional arguments about the family are based upon assumptions about the desirability of division of labour, socialization of children, and sharing sexual, affective and economic resources. Division of labour implies that women will specialize in affective tasks such as nurturing, solving emotional problems, kin-keeping, etc., while men concentrate on representing the family in the public sphere, assuring the families' economic wellbeing, and taking care of tasks that require physical power or expert knowledge (Parsons \& Bales, 1955; Zelditch, 1995).

Feminists claim that the functionalist views about the structures and the functions of families represent only a small portion of the variation in families (Eichler, 1997; Luxton, 2001). In reality, people who consider themselves and who are considered by others as a family may not live in the husband/wife/children form (divorced, widowed, childless are some variations). Moreover, they may not be heterosexual, they may not share the same residence, or they may have external sexual relations. Conversely, some intact families may pose problems and dangers for women and children despite their structural intactness (dysfunctional families, abusive husbands, violence against children are some examples). In short, the structural aspect (intactness) does not necessarily guarantee equity or happiness.

Increased paid labour force participation of women in the west, feminists claim, has made the traditional arguments obsolete. In fact, the merit attributed to traditional roles, hide the deep divide about the extraordinary burden women shoulder as paid workers/mothers/wives and kin-keepers (Armstrong \& Armstrong, 1984; Hartman, 1976; Hochschild, 2001; Fox \& Luxton, 2001). In patriarchal portions of the developing world, the division of labour arguments have been used to keep women out of the paid labour force, 
engendering a life-long dependence on men. Indeed, feminists claim that the structural functional arguments about the family are exactly what androcentric societies have prescribed and reinforced through policies and procedures.

Feminist theories analyze family life within the material conditions that surrounds it (Hartman, 1979). For example, how do laws, policies, economic conditions impact family life? In addition, the availability of adequate housing, accessibility of health and child-care services also are taken into account, along with the status of women in a given society (Eichler, 1997). Feminists are also cognizant about cultural variations, which may put additional pressures on women from patriarchal societies. In essence, families are not seen as occurring or dissipating in a vacuum but are analyzed as firmly embedded in the material and cultural conditions that either promote or hamper their growth.

Within feminist theories, whether power is distributed amongst family members or whether it is concentrated in the hands of men become issues of inquiry. What is crucial to understand is the position of women and girl children, vis-a-vis men and boys (Kagitcibasi, 1993; Kandiyoti, 1988). In patriarchal societies, women/female children have much less access to resources such as adequate food, clothing or schooling. In difficult times, their share of the resources may further dwindle (Chopra, 2002; Wolf, 2000). Another aspect feminists emphasize is whether women have decision-making power or whether decisions are made for them.

This paper adds to the above-summarized traditional debates about the family. What is pursued here is how some patriarchal societies manipulate the "intact family" expectations to an extreme and in doing so, subjugate women and children. Under the auspices of paternalist protectionism, what in fact transpires is that women's choices and their children's access to opportunities are circumvented to fit male priorities and privilege.

This article explores sororat (S) and levirat (L) types of marriages. The first refers to the patriarchal practice of a man marrying his wife's sister in case of the death of his wife. The second refers to the practice of a brother of a man who has died, marrying his sister-in-law. Levirat or sororat types of marriages are perhaps the least well-known type amongst many family forms. This lack of knowledge is partially due to the fact that they are uncommon and 
they often take place amongst remote, rural domains of extremely patriarchal regions of developing societies. Moreover, people who engage in $\mathrm{L}$ or $\mathrm{S}$ types of marriages may also engage in other unions that may be prohibited by the laws of the state that govern them. For example, they may practice bigamous or polygynous marriages, child-betrothal, dowry or bride price. The state may also prohibit close-relative marriages like in-law marriages. The abovementioned reasons combine to make $\mathrm{L}$ and $\mathrm{S}$ marriages one of the most elusive and one of the most understudied forms of marriage. In our view, $\mathrm{L}$ or $\mathrm{S}$ marriage is one of many examples of traditional societies' condemnation of women to what Radhika Chopra (2002) calls a "subterranean" existence in kin-dominated households.

The forty-five participants of $\mathrm{L}$ or S marriages are selected from very remote and mostly poverty stricken pockets of southeastern Turkey. ${ }^{3}$ Although they are becoming very rare through "modernization" that is sweeping the globe, L and S marriages are family forms that personify all that is problematic in functionalist arguments. Our results will make it clear that $\mathrm{L}$ and $\mathrm{S}$ exemplify the patriarchal grip on women's lives under the guise of family obligations. Although the families remain "intact," and the land base they live on remains undivided, this intactness is achieved at the cost of the freedom of women to establish independent lives for themselves and for their children. What is sad is that women do see these traditions as a necessary evil to take care of their children since the same societies give no other alternative for them to be independent.

The following section provides some general information about Southeastern Turkey, where L and S marriages are still practiced. We will introduce the methods of our study, and our findings from our in-depth, face-to-face interviews with forty-five L or S marriage participants. Indeed, it is our intention to show how the economic dependence of women (and their children) and cultural expectations about women's rigidly defined familial roles turn them into pawns in marital decisions and exchanges. We are going to argue that the general functionalist arguments about keeping the families

\footnotetext{
${ }^{3}$ In Turkey, $\mathrm{L}$ or $\mathrm{S}$ marriages occur in regions where the Kurdish minority constitute a local majority, although the practice is not exclusive to the Kurdish Turks.
} 
intact may indeed be dysfunctional since, in some cases, they confuse rather than clarify roles and statuses. In the particular cases that we will address, nieces and nephews of one may become one's stepchildren with the passing on of a sister or a brother, and one's sister or brother-in-law may one day become a wife or a husband. Of course, it can be argued that given the poor, congested living environments in these regions where many family members from quite different age levels share sleeping arrangements, it is possible that familiarities and even attractions amongst brothers-sistersin-laws are part of the family dynamics. It can also be argued that these dynamics may serve a purpose in those cases where a partner is lost, and the young children get a chance to be raised by an already known aunt or an uncle who quickly moves into a parental role. The culturally sanctioned intra-family replacement system of a dissolved/broken family pair may be seen as more desirable to leaving widowed women to their own means, or leaving orphaned children - especially girl children - at the mercy of unrelated step parents. Indeed, some of these concerns are legitimate, especially within regions where "social" responsibility/safety concepts towards individuals/families are less than well developed. Nevertheless, they also serve as excusing the gender-based inequalities within patriarchal systems, and blocking routes for women to challenge the status quo. ${ }^{4}$ In this article, we argue that under the guise of "protecting women," L or S types of marriages represent nothing more than depriving women of choice over their bodies or inheritance.

Given a death of a previous spouse, $\mathrm{L}$ or $\mathrm{S}$ marriages make women sexually available for men who are already related to them through marriage.

\section{Some Fagts About Turkey And Southeastern Turkey}

In 1923, Turkey became a democratic, secular republic. From its inception to the current day, Turkey has aspired to establish a true westernized state with a constitution which gives equal rights to all its citizens, regardless of gender, race or religion (since 1924). Starting

\footnotetext{
${ }^{4}$ We are grateful to our anonymous reviewers who asked us to expand our discussion on functionality debates.
} 
from the mid 1920s, Turkish civil and criminal laws closely mimicked their westernized counterparts (Arat, 1996; Marcotte, 2003; Orucu, 1996; Tekeli, 1995). Turkish women became entitled to a vote in 1930, and have been elected to the Turkish Parliament since 1934 (Kidog, 1997; 1998; Kislali, 1996; Kocturk, 1992; Tokgoz, 1996). Turkey is one of the few democracies that has ever elected a female Prime Minister (Tansu Ciller), ${ }^{5}$ a feat that still escapes both Canada and the U.S. ${ }^{6}$ However, as both Marcotte (2003) and Nasir (1994) argue, states with a vast proportion of Islamic populations have not been able to resolve family based issues through the modernization of their laws. States with large Moslem constituents have always experienced tensions between laws versus traditions and practices (Marcotte, 2003).

More recently, Turkey has accelerated its westernization due to its aspiration to join the European Union. Bold initiatives in its penal and legal systems, improvements in its human and political rights, becoming signatory to various United Nations conventions and declarations (albeit with some reservations) are unquestionable affirmations of this modernization. Turkey's commitments include the signing of the CEDAW (United Nations Convention on Elimination of All Forms of Discrimination Against Women, 1979), DEVAW (Declaration on the Elimination of Violence Against Women, 1993) and CRC (Convention on the Rights of the Child, see UNICEF, 2000). In articles 5, 10 and 11, CEDAW requires the signatory states to eliminate discrimination against women in education, work or any other culturally prescribed roles. Moreover, in articles 16 and 19, CEDAW expands its requirements to the elimination of discrimination against women in family relations. Another United Nations Declaration (DEVAW, 1993), has aimed at the protection of women from early marriages or child-betrothals, family or husband violence, and unequal treatment in cases of divorce, widowhood or inheritance. Thus, the declarations Turkey has signed make it clear that women's issues are no longer left to the whim of

${ }^{5}$ In the Turkish Parliamentary System, the leader of the party which receives the highest number of votes becomes the Prime Minister. In that sense, Ciller was selected by her party, and the party was elected by the voters.

${ }^{6}$ After Prime Minister Brian Molroney's resignation, Kim Campbell served as the Prime Minister of Canada for a few months, but she was never elected or re-elected to this position. 
individual states, but form serious and integral human rights issues with global significance (Bond \& Phillips, 2001; UNIFEM, 2001).

Despite all these positive developments, Turkey continues to experience economic, social and structural challenges. For example, a large population, a modest land-base, high birth rates, high infant and maternal mortality rates, low life expectancy and extreme regional variations in wealth and standard of living persist (Akyildirim, 2001). What also needs to be emphasized is that parts of Southeastern Turkey are caught in a time warp (see Table 1 for some sociodemographic comparisons). In Collins's (2004: 4) words: “Turkey is a country of contradictions. Its major cities are modern and sophisticated, but rural Turkey is a long way from the country's cultural capital of Istanbul. The village is where the old ways live on." Especially in the patriarchal southeastern Anatolia, women's and young girls' lives basically remain at the mercy of their male relatives and kin (Sev'er \& Yurdakul, 2001). Despite modernized Turkish civil laws, girls can be betrothed, married to much older men to settle family disputes, or can be bartered in marriage by families who want to avoid paying bride-price. Bride price is paid to the bride's family, but poor families often keep what is given rather than passing it on to the brides. In very poor regions, nothing of any worth may change hands except for some services (the groomto-be may fix the leaking roof of the home where the bride's family lives). Both the bartering and the bride-price systems are against Turkish laws, but this fact does not prevent their frequent occurrence in the region. In Kurdish, barter is referred to as "berdel" which means that a sister/brother are wed to a brother/sister pair. This is not a comment about Islamic rules, but about Kurdish 'berdel traditions'. Most Kurds are Moslems. (Ilkkaracan, 2000). Yet, if either one of these marriages fails (even by death), the other marriage is also considered obsolete, leaving women and children always anxious about their future.

Additional problems pertain to women's work. Although most women in the southeast work very hard in either paid labour force (as farm labourers or as factory workers in the cotton or rugmaking/pottery industries) or within kin-owned farms, they rarely have access to the money they make. Their legal right to inherit from fathers and husbands may also be circumvented through manipulation of marriage systems. The fact that girl children are 
much less likely to be sent to school, and much more likely to be illiterate compounds the matter. Bound by cultural practices, women are rarely in a position to demand their legal rights in work, education, inheritance or marriage (Kidog, 1997; 1998). Many marriages in Southeastern Turkey are polygamous (Elmaci, 1996).

In southeastern Turkey, especially amongst the Kurdish minority, a cultural pattern that disadvantages women is regionally felt revulsion against property splits. A region that is blistered by plus $40 \mathrm{C}^{\circ}$ temperatures, that lacks adequate water supplies and is devoid of fertile soil or other natural resources makes the rationale for this revulsion obvious. Large families cannot survive on minute parcels of land. In contrast, Turkish inheritance laws are egalitarian and demand equal treatment of men/women or boys/girls in cases of death within legal marriages. To keep the land intact, rural people use numerous loopholes to circumvent egalitarian laws and effectively deprive women and girl children from their legal inheritance. One way is to perform marriages as a "religious" ceremony, which carries cultural importance but no legal protection for women. Legally, their children are considered to be born out of wedlock, and deprived of inheritance. Moreover, contrary to the monogamous legal marriages, religious marriages can be polygamous. Another way is to shift widows onto another male member of the patriarchal clan. Usually the shift takes place from a deceased to a surviving brother $(\mathrm{L})$. Some men are encouraged to marry their sisters-in-law when their own wives die $(\mathrm{S})$, especially in cases where there are young children. Given the high mortality rates in the region (Table 1), these $\mathrm{L}$ or $\mathrm{S}$ marriages can be a frequent occurrence. The sister of the deceased wife is seen as de facto surrogate mother, regardless of her own desires, aspirations or age. Despite this functional convenience, we believe that male dominance over land/family resources spills over to the treatment of women as "family property." In turn, these reasons are used to justify L or S marriages. 
Table 1: Selected demographic indicators from three regions of our study in southeastern Turkey (Diyarbakir, Mardin and Sanliurfa)

\begin{tabular}{lcccc}
\hline & TURKEY & \multicolumn{2}{c}{ THREE REGIONS OF OUR STUDY IN } \\
& & \multicolumn{2}{c}{ SOUTHEASTERN TURKEY } \\
& & DIYARBAKIR & MARDIN & SANLIURFA \\
\hline Population (x 000) & 65,293 & 1,182 & 689 & 1,460 \\
Population increase (\%) & 1.48 & 2.2 & 2.1 & 3.8 \\
Gross birth rate (per 000) & 21.5 & 37.6 & 37.4 & 35.6 \\
Gross death rate (per 000) & 6.7 & 6.5 & 9.8 & 4.7 \\
Average \# of children & & & & 4.9 \\
$\quad$ per adult women) & 2.5 & 4.3 & 5.1 & 37.4 \\
Infant mortality rate & & & 71.1 & 69.5 \\
(per 000 live births) & 35.3 & 55.0 & 59.8 & 67.4 \\
Life expectancy (overall) & 69.1 & 63.0 & 57.7 & 71.6 \\
For men & 66.9 & 61.0 & 61.9 & 47.1 \\
For women & 71.5 & 65.2 & 46.5 & \\
\% of women in population & Not available & 47.4 & \\
\hline
\end{tabular}

Source: Akyildirim, 2001

\section{Fundamentalist Fustifications}

Although Turkey is a secular democracy, which meticulously segregates religion from governmental affairs, the fact remains that close to 99 percent of its population is Moslem. In stringently patriarchal pockets such as the southeast, Islamic teachings and practices still form a strong basis for how people organize their lives (Collins, 2004). Islamic traditions are based on the Qur'an (the holy book), the hadiths (prophet Mohammad's behaviour and sayings), and the Sharica (Islamic code of law). Despite secular Turkish modernism, some justification for $\mathrm{L}$ or $\mathrm{S}$ types of marriages is resurrected from the Qur'an and the hadiths by religious fundamentalists. What is unfortunate in these fundamentalist resurrections is that practices, which were devised solely for the well-being of women and their children in the 7th century $\mathrm{AD}$ are now twisted to deprive women of choice and freedom. This article argues that patriarchy as a system feeds on gendered inequalities. In other words, patriarchy is not a benign force. Intentionally or because traditions die so slow? (Goodwin, 2003; Kandiyoti, 1997; Kocturk, 1992; Marcotte, 2003).

The Qur'an allows up to four wives for men, especially if the death of their wives has left them with young orphans. However, this permission comes with very stringent expectations: "If you fear 
that you cannot treat orphan [girls] with fairness, then you may marry other women who seem good to you: two, three or four of them. But, if you fear that you cannot maintain equality among them, marry one only... (The Qur'an, 1976 translation, p. 366; elaboration of orphans as [girls] in original translation). The Qur'an also clearly states: "it is unlawful for you to inherit the women of your deceased kinsmen against their will, or bar them from remarrying ..." (The Qur'an, 1976: 368). The prophet Mohammed, after a monogamous and egalitarian relationship with his first wife (Khadija), married numerous women upon her death. All but one of Mohammed's wives were war widows (Goodwin, 2003), and the hadiths show his painstaking effort to treat them equally.

Thus, although the free choice of women in marital decisions is entrenched in Turkish laws as well as in The Qur'an, the current practice of L or $\mathrm{S}$ marriages in southeastern Turkey deviates from both aspirations that uphold women's choice.

\section{Methods}

The current study is based on a convenience sample of forty-five. A snowballing technique was used to recruit participants who were either living or have recently lived in an L or S marriage. Interviews were conducted in a face-to-face setting, at the convenience of the participants. ${ }^{7}$ The majority of interviews took place at remote village homes. Participants were informed of the nature of our study, and no deception was used. They were clearly told that they would never be identified, the results of the study will only be used in teaching and academic publications, and they were free to withdraw from the study or refrain from answering a particular question any time they wished. Since most of our participants were illiterate or barely literate: only a verbal consent was required. Moreover, since numerous participants were monolingual, some interviews were conducted in Kurdish and other interviews were conducted in Turkish. All responses were recorded in Turkish.

\footnotetext{
7 Two male and two female graduate research assistants who spoke fluent Turkish and Kurdish carried out the interviews. Females interviewed female respondents, and males interviewed male respondents.
} 
The study was conducted during the summer of 2003. Interviews lasted between one to two hours. The length of the interview was determined by the willingness of the participants to elaborate on the open-ended questions. Although gentle probes were used in predetermined portions of the interviews, participants were free to elaborate or not to elaborate. Most were eager to talk about issues which, they told us, have never been asked of them before. Interviews with women participants took longer than interviews with male respondents (average of one hour versus one-and-a-half hours).

\section{Questions}

Our questionnaire can be summed up in four categories. The first part was the usual sociodemographic variables about gender, age, education, income, rural/urban location, marriage type, number of marriages, and number of children (if applicable, from different marriages). A second set of questions explored the general perceptions of marriage, and general attitudes towards $\mathrm{L}$ or $\mathrm{S}$ types of marriages. In the latter, we were particularly interested in finding out how the participants justified this type of marriage (within personal, parental, familial, kin or religious terms). We were also interested in seeing whether men and women differed on their attitudes and perceptions about forming $\mathrm{L}$ or $\mathrm{S}$ unions.

Our third set of questions explored the decision making process: whether the consent of the woman/man was sought, who made the final decision, and whether the woman/man had any veto power over the decision.

The last set of questions concerned roles and role confusion, and the emotional responses to the shifting roles in $\mathrm{L}$ or $\mathrm{S}$ marriages. In this portion, we asked our respondents about their emotions that accompanied the consummation of their $\mathrm{L}$ or $\mathrm{S}$ marriages. More specifically, we asked our respondents about how they felt during the first night of their marriage. Given our knowledge of the culture, we had no doubt that men would be quite forthcoming, but we were not sure about the reactions from our female participants. To our surprise, our fears about women being too shy to answer this question did not materialize. Instead, almost all female respondents were eager to talk about their emotional turmoil. Most male respondents expressed joy rather than turmoil (see Table 2). It is possible 
that some of the gender differences we observe are due to normative expectations. For example, especially in traditional cultures, males are expected to be the assertive initiators and leaders in all matters of sexuality. Females are expected to be shy and reserved. Talking about sexual relations on the first night of marriage may have triggered some of these deep-rooted expectations. Unfortunately, our study cannot definitively tease out the differences due to cultural and normative expectations versus differences due to the $\mathrm{L}$ or $\mathrm{S}$ marriages. However, if one considers the strength of the reactions by numerous women, which a likened the first night of their $\mathrm{L}$ or $\mathrm{S}$ marriage to death, one can see that what we are observing here goes beyond culturally prescribed shyness. ${ }^{8}$ (Would cultural expectations be part of the reason for these reactions? Women are generally expected to be shy and I turmoil of what takes place on a wedding night while males are supposed to be aggressive and sure of themselves. Were such questions asked or taken into consideration?)

In this portion, we also inquired about how children responded to the changing roles, were they were negatively affected by the switch (from uncle to father and from aunt to mother), and whether there were tensions and mixed loyalties amongst children and parents from different sets of unions.

The final question we asked explored whether our male and female respondents were happy with their gender, or would have liked to be born as a member of the opposite sex. Not surprisingly, none of the men wanted to switch to being a woman, but all but five women wished they were born as a man (see Table 3) (Very interesting. Did age have anything to do with this?).

\section{FINDINGS}

\section{Sociodemographic characteristics}

Sex: Twenty-six women and nineteen men (total = forty-five) who were currently living or have lived in an L or S marriage participated in our study.

${ }^{8}$ We thank one of our anonymous readers for suggesting to elaborate on the role of gender norms and expectations in interpreting the different reactions to the first night. 
Age: Eight participants were between twenty-six and thirty; eighteen participants were between thirty-one and forty and nineteen participants were over forty years of age.

Education: Thirty-two (71 percent) of our participants were illiterate or semi-literate, and eleven (24 percent) had an elementary school education. Only two (4 percent) had attended or completed high school, which in Turkey, goes up to grade 8 .

Income: Our respondents were from the poorest segment of the poorest region of the Turkish society. Indeed, forty-one (91 percent) came from families, which made less than $\$ 600$ per year. The family income of the remaining three $(7$ percent) was between $\$ 601-1000$. Only one of our respondents (2 percent) reported an annual family income of over $\$ 1,000$. It should be underscored that these are annual "family" incomes. ${ }^{9}$

Occupation: Twenty-two respondents were housewives. The remaining occupations reported were mostly in farming (7 or 16 percent), small merchant ( 4 or 9 percent), and labourer ( 2 or 4.5 percent) categories. Eight (18 percent) were not employed or semi employed in transient jobs.

Regions and rural/urban residence: Our respondents came from three regions of southeastern Turkey. Fifteen (33 percent) were from Diyarbakir, thirteen (29 percent) from Mardin, and seventeen (38 percent) from Sanliurfa regions and their villages. Thirty-one (69 percent) of our forty-five respondents lived in small or very small villages. Fourteen (31 percent) lived in impoverished zones of a town or a city. These zones are generally referred to as "varoş" and resemble the destitute North American ghettoes. However, residents of varos areas are often docile and much more resigned to their fate than their North American counterparts. Gang violence is unheard of despite the poverty in varoşes.

Marriage type and previous marriages: At the time of the interviews, 29 (64.5 percent) respondents were "legally" married. Sixteen (35.5 percent) were married through a religious ceremony alone, which the

\footnotetext{
${ }^{9}$ Despite very low incomes, it should be noted that these people are not starving, since they farm patches of land, raise chickens, ducks, goats and sheep, make their own clothing and travel in horse or mule-drawn buggies.
} 
Turkish family law does not recognize as a legal marriage. Over 62 percent of our respondents (twenty-eight) reported living in a $\mathrm{L}$ marriage. An additional 29 percent (thirteen) lived in S marriages. Four respondents (10 percent) lived in more complex family forms (i.e., L or $\mathrm{S}$ combined with multiple wives). Moreover, twentyseven (60 percent) of our respondents were previously married. For 16 (35.5 percent), the $\mathrm{L}$ or $\mathrm{S}$ marriage was their only marriage (2 had more complex configurations).

Number of children: Forty-one (91 percent) respondents had a total of 228 children. Of the 228, seventy-five were from earlier marriages and the remaining 153 were from L or S marriages. Only four (9 percent) respondents had no children.

Duration of $L$ or $S$ marriages: The duration of $\mathrm{L}$ or $\mathrm{S}$ marriages of our respondents ranged from two to forty-two years $($ mean $=15)$.

House composition: thirty-one respondents (69 percent) lived in nuclear types of families at the time of the interviews. Six (13 percent) lived in an extended family context (with parents or with in-laws). The remaining eight had more complex arrangements (multiple wives, concubines or living with brothers and uncles).

\section{General Attitudes}

We asked our participants what they thought about marriage as an institution. Twenty-five (55.5 percent) said that partners should be able to freely talk to each other and communicate with each other. The remaining responses we received were varied: Four (9 percent) each said marriage should be seen as a religious or as a family obligation. Three ( 7 percent) each said that marriages should make men the dominant person of the house, or should be organized to please family and kin. An additional two (4.5 percent) claimed that marriage was a must for the continuation of their traditions. We classified the responses under egalitarian or traditional or very traditional views about what marriage was seen as. $\mathrm{A} \mathrm{Chi}^{2}$ analysis showed the gendered differences in opinions about marriage. Women thought that marriages were constructed for much less egalitarian values than men did $\left(\mathrm{df}=2, \mathrm{Chi}^{2}=10.0, \mathrm{p}<.01\right)$.

When we asked our respondents about what they thought about $\mathrm{L}$ or $\mathrm{S}$ marriages, the range of responses we got were quite varied. 


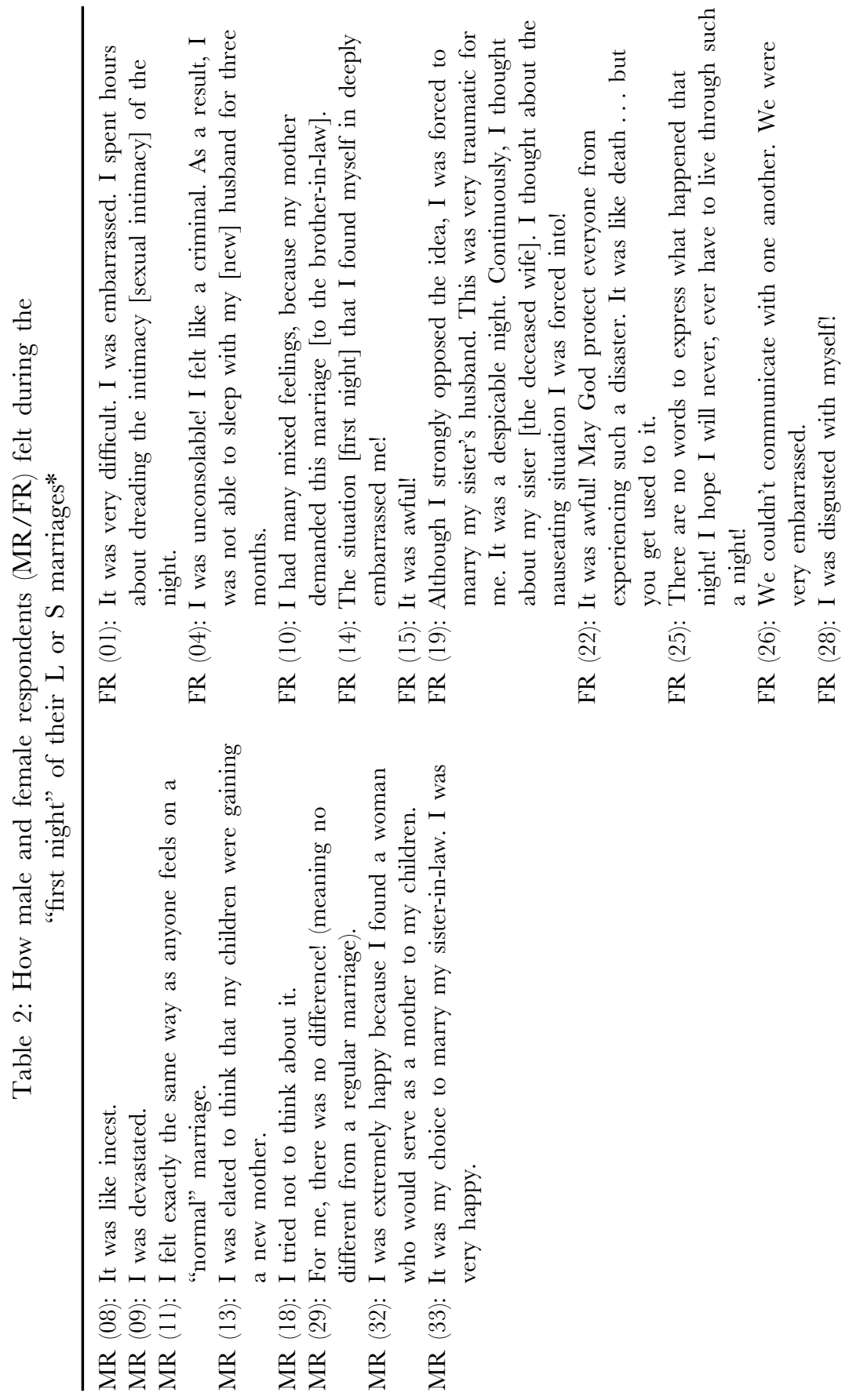




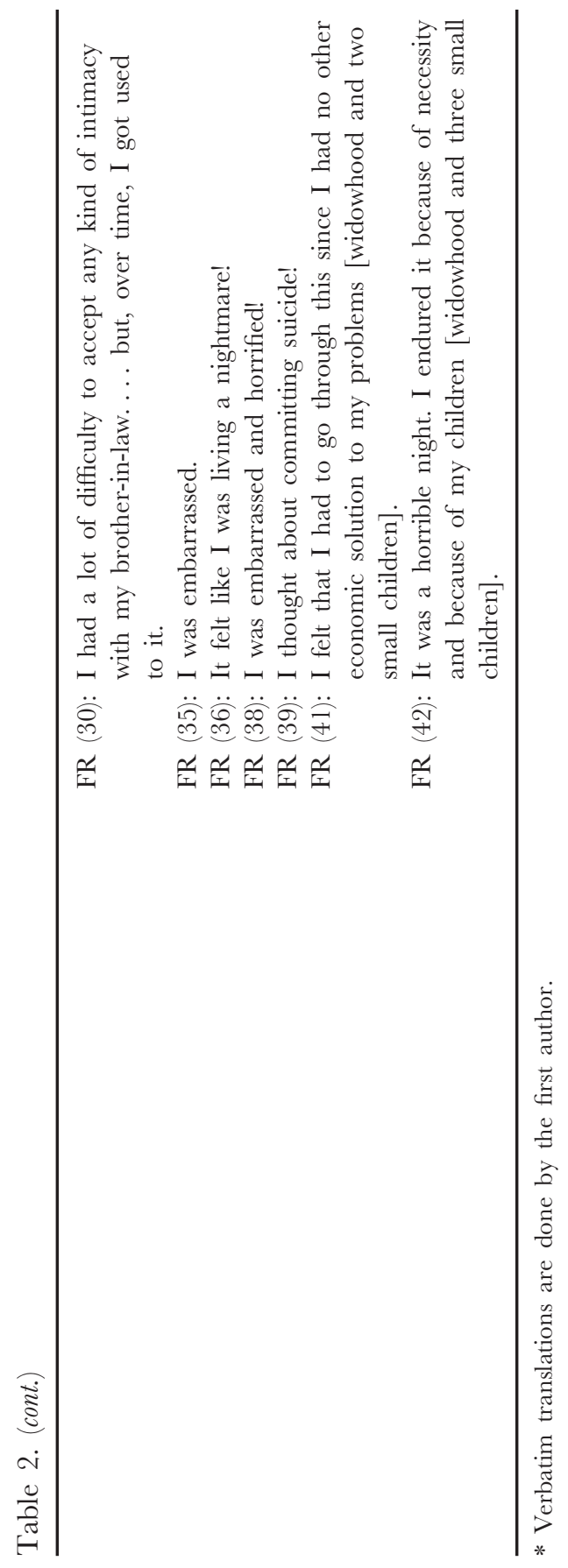


Twenty-two (49 percent) said such marriages were "normal" for cultural, traditional or religious reasons. Nine (20 percent) said they were necessary for the sake of women and children and an additional 3(6.5 percent) said they were necessary for men and their children. Ten respondents (22 percent) expressed strong objections to the lack of choice in such arrangements. We again classified the responses under egalitarian or traditional or very traditional views. Our analysis clearly showed that our male and female respondents differed in their attitudes toward L or S marriages. Women were much less likely to find these arrangements acceptable than men $\operatorname{did}\left(\mathrm{df}=2, \mathrm{Chi}^{2}=6.5, \mathrm{p}=.03\right)$.

We also inquired about who is most likely to be affected by $\mathrm{L}$ or $\mathrm{S}$ marriages. Twenty-one respondents said it was women, twelve said children; four said it was men and seven claimed it was the family in general. An analysis of the gendering of these responses produced significant differences $\left(\mathrm{df}=3, \mathrm{Chi}^{2}=27.3, \mathrm{p}<.001\right)$. Interestingly, more women thought that $\mathrm{L}$ or $\mathrm{S}$ types of marriages would affect women and children. When we asked if these effects would be negative, again we observed a highly significant gender difference $\left(\mathrm{df}=3, \mathrm{Chi}^{2}=35.8, \mathrm{p}<.001\right)$. Apparently, men are under the illusion of thinking that $\mathrm{L}$ or $\mathrm{S}$ types of marriages benefit women, whereas women perceive these arrangements as adverse, but unavoidable intrusions.

When we followed up with the question about who benefits from $\mathrm{L}$ or $\mathrm{S}$ types of marriage, sixteen (35.5 percent) stated that children do. An additional ten (22 percent) stated that family, nine (20 percent) claimed that women were the beneficiaries. Three (7 percent) thought that the tribe, and an additional three ( 7 percent) thought that men benefited the most. Four respondents (9 percent) gave other answers. What is interesting in these responses is that children's and family's benefit is assumed to outweigh women's and men's benefit from the L or S marriages. There is no gender difference in this variable.

\section{Decision Making Process}

Twenty-three (53 percent) respondents admitted to being pressured to making the $\mathrm{L}$ or $\mathrm{S}$ type of marriage. Twenty-one (46 percent) did not mention pressure, and one person chose not to respond to 
this question. What is more interesting is the "source of pressure" respondents identified in the following question. Fifteen (33 percent) respondents said they were pressured by their families, four (9 percent) by their fathers, and one each (7 percent) by their mothers or father/mother in-laws. An additional two (4.5 percent) blamed traditions. When we asked who was ultimately responsible for the L or S marriage decision, only six (13 percent) said that it was up to them. Nineteen (42 percent) claimed that the decision belonged to their families, 8 (18 percent) attributed the decision to their parents, and an additional 7(15.5 percent) to their relatives. Thus the decision can be easily interpreted as belonging to the family/kin, not to the individuals.

To further understand the decision making process, we asked our male and female participants if men had some kind of a veto power over the family decision about L or S marriages. Thirty-two respondents (71 percent) said that men had the power to block an unwanted marriage. When we asked the same question about women's veto power, only sixteen (35.5 percent) of our respondents mentioned that women could object. The difference between type of marriage ( $\mathrm{L}$ or $\mathrm{S}$ or complex), gender ( $\mathrm{M}$ or $\mathrm{F}$ ) and perceived male veto (yes or no) power is a statistically significant difference $\left(\mathrm{df}=2, \mathrm{Chi}^{2}=\right.$ $32.9, \mathrm{p}<.001)$. Conversely, the relationship amongst the type and gender variables with female veto power is not statistically significant $(\mathrm{df}=2$ Chi2 $=3.75, \mathrm{p}>.05)$. These analyses show the relative power of men to have their say but the perceived powerlessness of women (as acknowledged by both men and women) in L or S marriages.

\section{Roles and role-shifts}

Before we asked our respondents about roles and role shifts, we asked them about the role of women in marriages. Nineteen (42 percent) claimed that women's role was to serve their family, another nineteen (42.5 percent) stated that women's role was to assure the happiness of their families. Only seven (15 percent) said that married women could pursue their individual wants. There were no significant gender differences on these perceptions.

Our last set of questions probed the tensions in the roles and role shifts due to $\mathrm{L}$ or $\mathrm{S}$ marriages. We first inquired about how our respondents dealt with children from their own or their partner's 
previous marriage or their mutual children from the current marriage. Twenty-eight (62 percent) respondents said that their treatment of the different sets of children were the same. However, 3(6.5 percent) claimed that they liked the current, seven (15.5 percent) said they liked their own children from the previous marriage, and two (4.4 percent) claimed that they liked their stepchildren more. The rest had no children.

We also asked how they felt the different sets of children treated the new set of parents. Twenty-six (58 percent) of our respondents reported no difference. However, six (13 percent) claimed that their previous children loved them more, and three ( 6.5 percent) felt that their current children loved them more. Five (11 percent) of our respondents expressed dissatisfaction about how they were being treated by all their children.

We asked our respondents whether they made comparisons between their old versus $\mathrm{L}$ or $\mathrm{S}$ marriages to a problematic degree Five $(11$ percent) respondents said they made comparisons very often, and eighteen (40 percent) said they made comparisons some of the time. Almost fifty percent of our respondents did not identify past/current marriage comparisons as a problem in their lives.

For a few women, there was the burden of becoming an extra wife in a polygamous marriage. For example, FR (01) stated that her husband spends one week with her and one week with his other wife. FR (39) has to live with two other wives and their children of her L husband. Four other women reported currently living with their children, husbands, in-laws, as well as brothers-in law and their families. Our research cannot bring illumination on how our respondents may have been affected by these complex, and often undesirable living arrangements. However, these complexities are congruent with our position that women's wishes and perceptions are rarely taken into account in marriage formulations.

We believe that one of the questions that produced the most insightful response is the question about how our respondents felt during the first night of their marriage. Qualitative responses about the first night are revealing, both in and of themselves, and in terms of the gender differences (see Table 2). Overall, seventeen respondents said the first night was extremely difficult. An additional seventeen said it was difficult. Only six respondents (five of whom were men) claimed that the first night of the $\mathrm{L}$ or $\mathrm{S}$ marriage was 
normal or pleasant, while another five did not elaborate. When we analysed these opinions on the basis of gender, the emotional turmoil women experienced became clearer $\left(\mathrm{df}=2, \mathrm{Chi}^{2}=19.6\right.$, $\mathrm{p}<.001)$. As Table 2 clearly shows, women talked about feeling awful (FR 15, 22), feeling like a criminal (FR 04), being inconsolable (FR 04), feeling disgusted (FR 28), being nauseated (FR 19), and even thinking about suicide (FR 39). Others used terms like a nightmare (FR 36), horrified (FR 38), and horrible (FR 42). One woman (FR 25) claimed that there are no words to express how she felt. One woman (FR 22) compared the experience to "death".

In contrast, most male respondents either did not bother to elaborate on their answer or expressed pleasure with the experience (see Table 2). Although our question was specifically about the first night, a few men chose to cloak their elation as being pleased for the sake of their children (MR 13,32). To be fair, two male respondents (MR 08, 09) were also traumatized by the role shift, but they were the exception than the rule. The real trauma showed in the experiences of almost all women (see Table 2).

Another revealing question pertains to whether our respondents were content with their own gender or wished to be a member of the opposite sex. Not surprisingly, all men felt content as men. In explaining their satisfaction, male participants either emphasized the value of men or the helplessness and oppression of women (see MR responses in Table 3). In contrast, all but five women wished they were born as a man. Their justifications highlighted the pressure, control, workload and lack of freedom and lack of choice for women (see FR responses in Table 3). As one woman (FR 25) put it, "they can say "no'?" What is interesting is the congruence between how both men and women see the "value" their culture places on men. This mutual recognition explains why men are happy as they are, but women wish they were men.

\section{Summary And Discussion}

In the present study, we tried to understand the structural determinants as well as the dynamic of $\mathrm{L}$ or $\mathrm{S}$ marriages which are still practiced in remote, patriarchal regions of south eastern Turkey 
(you do not show how this applies in patriarchal regions outside of southeastern Turkey, perhaps you should indicate that). Our respondents live in or around Diyarbakir, Mardin and Sanliurfa regions. We interviewed forty-five men/women who were currently living or have recently lived in one of these types of marriages. Other than their marginally higher poverty and lack of education, our respondents are similar to the people of the region, although the region as a whole is substantially different from most of the modernized portions of Turkey.

What we found is that $\mathrm{L}$ or $\mathrm{S}$ types of marriages are difficult, even for people who are socialized to think of these marriages as unavoidable. The difficulty arises from women's lack of input into the decision-making process as well as the confusion of roles these types of marriages engender. Although family and kin pressure on men seem to be almost as pronounced as they are on women, men at least seem to enjoy a veto power over the issue. In the rare occasion when a younger man uses his veto power, one of the older and possibly less desirable male relatives/kin may take on (marry) the widowed woman and her children. In a world where women are deprived of their social and economic autonomy, their choice in marital matters is negligible. (in that case who takes over the responsibilities for supporting the widow and orphans? Are there other conditions that give men this type of freedom?). The fact that women do not have veto power, adds to their anguish. What is interesting in our findings is that both men and women equally agree on the relative powerlessness of women (Table 3).

Approximately 58 percent of our respondents did not find raising children from different but closely related family formations to be a problem. However, tensions were apparent in the others. Numerous respondents expressed displeasure about how their different sets of children treated them. Some also confessed that they themselves had positive or negative preferences towards their own or their L or S partner's previous children.

Our results also indicated that although these marriages are difficult for a few men and for almost all women, men seem to be under the illusion that these marriages are doing a favour to women and their children. Women recognized the adverse effects of such marriages, but at the same time, realized that they did not have 
alternatives. After telling us how "awful" and "like death" the first night was, a respondent twenty-two-year-old went on to elaborate on her helpless resignation: "if the [economic] circumstances were different, and if I were a man, my life would have been completely different. I would have had a career, a job and economic independence. I wish I had economic independence.... but there is none! When you don't have [economic] safety, the worst things happen to you" [in her case, L type marriage]. Respondent 04 (Table 3) also noted: "if I were a man, I would have a job. I would have been able to choose my partner."

A society which deprives women of economic independence is a society that condemns them to live their lives as appendages of men, whether they like it or not (agreed, but is this due to poverty? Are there economic possibilities in these regions?). Southeastern Turkey is generally poor, with very high levels of unemployment and under-employment. However, the overall difficult conditions take on an even more ominous character for women and girls who are deprived from schooling, are married off in early ages, and have almost no access to whatever meagre resources their families may have. They live under kin supervision and domination. Their gendered dependencies are easily singled out from the general socioeconomic difficulties in the region. Therefore, it is our contention that if these women had the economic ability to sustain themselves and their children, most would actively resist $\mathrm{L}$ or $\mathrm{S}$ types of marriages. In their own words, the role shift, especially the part that involved sexual intimacy with their brothers-in law, was traumatic for them (Table 2). Although men and women were only slightly differentiated on their views about the traditional roles of women within the family (i.e., as sacrificing for the extended family and family happiness), these traditional attitudes did not make the role shift any easier for women. Most wished they were born as men in order to escape their gendered predicament (Table 3).

In our opening comments, we highlighted the fact that Turkey is a signatory to CEDAW (1979) and DEVAW (1993). Both hold the states responsible for directly protecting women from all types of discrimination and violence. DEVAW also holds the states responsible for changing the conditions, which lead to or exasperate discrimination against women. Under pressure from women's groups, some other signatory states (such as India, Bangladesh and Sri Lanka) have 
started to recognize, at least to a limited extent, that inflicting mental anguish on women should become offences under their criminal laws (Goonesekere, 2004). So far, Turkish civil laws are not very effective in preventing $\mathrm{L}$ or $\mathrm{S}$ marriages, and Turkish criminal laws do not recognize the pressure on or the anguish women experience in $\mathrm{L}$ or $\mathrm{S}$ marriages as an offence. Thus, rural women who lack education and personal means for economic independence continue to find themselves dependent on husbands. In case of the demise of a husband, they become the property of brothers-in-law or other surviving male kin. Poor women also find themselves as replacement for their deceased sisters, regardless of their reservations about the role confusion. Their economic dependence translates into their being traded as possessions after the death of their husbands or their sisters. Although a few touched upon these types of families as a "religious obligation," such attributions were the exception rather than the rule. What really pushed these women into L or S marriages was their economic binds, and possibly, their lack of knowledge about their inheritance rights. Through $\mathrm{L}$ or $\mathrm{S}$ types of marriages, patriarchal families bypass the egalitarian inheritance laws, and keep the farming lands intact in the hands of tribes.

Although the "intactness" of families are favoured by all traditional societies (and traditional theories of family), sometimes "intactness" is attained by sacrificing free will and choice. As our findings clearly show, in cases of $\mathrm{L}$ or $\mathrm{S}$ marriages, this process is gendered. As we have shown in $\mathrm{L}$ or $\mathrm{S}$ marriages, women can even be made part of the inheritance package, rather than being allowed to inherit their fair share and pursue independent lives. As we tried to make clear, this is despite the modernized laws, and it is also in spite of some protection of women embedded in The Qur'an. Under the guise of "traditions," the real engine of marital forms is economics. What patriarchal societies proclaim to be "functional" to family or kin group is nothing but a traumatic intrusion on women who are made to survive in such unnatural arrangements.

\section{REFERENGES}

Akyildirim, Ozlem. Demografik Yapi: Gap Bolgesinde Mevcut Durum ve Egilimler (Demographic Structure: The Current State and Prospects for the Gap Region). Ankara: T.C. basbakanligi Gap Bolge Kalkinma Kurumu (Turkish Republic Government: GAP Regional Development Institution), 2001. 
Arat, Nurhan (ed.). Turkiye'de Kadin Olmak (Being a woman in Turkey). Istanbul: Say. Armstrong, P. \& Armstrong, H. (1984). The Double Ghetto: Canadian Women \& Their Segregated Work. Toronto: McClelland, 1996.

Bond, Johanna \& Phillips, Robin. Violence against women as a human rights violation. In. C.M. Renzetti, J.L. Edelson \& R.K. Bergen (eds.). Sourcebook on Violence Against Women. Thousand Oaks, California: Sage, 2001.

Collins, Catherine. Some in rural Turkey wedded to polygamy: Legal reforms threaten tradition. Chicago Tribune, Sept 25, 2004, p. 4.

CEDAW. 1979. Http://www.un.org/womenwatch/daw/cedaw (Last visited, Oct. 2003).

Chopra, Radhika. (Ed.). From Violence to Supportive Practice: Family, Gender and Masculinities in India. New Delhi: UNIFEM 2002.

DEVAW. 1993. Http://www.un.org/womenwatch/daw/devaw (Last visited, Oct. 2003).

Echleman, J. Ross \& Wilson, Susannah J. The Family (3rd ed.). Toronto: Pearson, 2001.

Eichler, Margrit. Family Shifts: Families, Policies and Gender Equality. Toronto: Oxford, 1997.

Elmaci, Nuran. Poligami: Cok esli evlilikler (Polygamy: Marriage to multiple partners). Pp. 79-124 in N. Arat (ed.). Turkiye'de Kadin Olmak. Istanbul: Say, 1996.

Fox, B. \& Luxton, M. Conceptualizing family. Pp. 22-33 in B. Fox (ed.). Family Patterns \& Gender Relations. Toronto: Oxford, 2001.

Goodwin, Jan. Price of Honor. New York: Plume, 2003.

Goonesekere, S. (Ed.). Violence, Law \&ु Women's Rights in South Asia. New Delhi: Sage, 2004.

Hartman, Heidi. Capitalism, patriarchy and job segregation by sex. Pp. 137-169 in M. Blaxall \& B. Reagan (eds.). Women in the Workplace. Chicago: Chicago University Press, 1976.

Hochschild, A. The third shift. Pp. 338-352 in B. Fox (ed.). Family Patterns $\mathcal{E}^{\circ}$ Gender Relations. Toronto: Oxford, 2001.

Ilkkaracan, P. Exploring the context of women's sexuality in Eastern Turkey. Pp. 229-243 in P. Ilkkaracan. Women \& Sexuality in Muslim Societies. Istanbul: Women for Women's Rights, 2000.

Kagitcibasi, Cigdem. The old age security value of children and development. Pp. 113-117 in L. Tepperman \& S.J. Wilson (eds.). Next of Kin. Englewood Cliffs, New Jersey: Prentice Hall, 1993.

Kandiyoti, Deniz. Cariyeley, Bacilar, Murttaslar (Sex-Slaves, Sisters \& Citizens). Istanbul: Metis Kadin Arastirmalari, 1997.

Kidog. Education, Legal Status, Reproductive Health: Women in Turkey. Istanbul: Kidog (NGO Advocacy Network for Women), 1997.

-. In light of International Declarations: Women in Turkey. Istanbul: Kidog (NGO Advocacy Network for Women), 1998.

Kilbride, Philip L. Plural Marriage for Our Times: A Re-invented Option? Connecticut: Bergin \& Garvey, 1994.

Kislali, A.T. Ulusal egemenlik ve siyasette kadin (National Independence and women in politics). Pp. 73-78 in N. Arat (ed.). Turkiye'de Kadin Olmak. Istanbul: Say, 1996. 
Kocturk, Tahire. 1992. A Matter of Honour: Experiences of Turkish Women Immigrants. London: Zed, 1992.

Luxton, M. Family coping strategies: Balancing paid employment \& domestic labour. Pp. 318-337 in B. Fox (ed.). Family Patterns \& Gender Relations. Toronto: Oxford, 2001.

Marcotte, Roxanne D. How far have reforms gone in Islam? Women's Studies International Forum 26(2) (2003): 153-166.

Nasir, Jamal J. The Status of Women under Islamic Law and Under Modern Islamic Legislation. London: Graham \& Trotman, 1994.

Orucu, E. Hukukta kadin ve son gelismeler. (Women within the law and the latest developments). Pp. 21-42 in N. Arat (ed.). Turkiye'de Kadin Olmak. Istanbul: Say, 1996.

Parsons, T. The American Family: Its relation to personality and to social structure. Pp. 3-33 in T. Parsons \& R.F. Bales (eds.). Family, Socialization \& Interaction Process. New York: Free Press, 1955.

Ramu, G.N. 1993. Introduction. Pp. 1-17 in G.N. Ramu (ed.). Marriage \& the Family in Canada (2nd ed.). Toronto: Prentice-Hall, 1993.

Sev’er, Aysan \& Yurdakul, Gokcecicek. 2001. Culture of honor, culture of change: A feminist analysis of honor killings in rural Turkey. Violence Against Women, 7(9) 2001: 964-998.

Tekeli, Sirin (Ed.). 1995. Women in Modern Turkish Society: A Reader. London: Zed, 1995.

The Qur'an (Translated with notes by N.J. Dawood). New York: Penguin, 1976.

Tokgoz, Oya. Siyasal reklamlarda kadin soylemi ve kadin imgeleri ornel olarak 1987 ve 1991 genel secimleri (Examples of depictions of women in political ads and the 1987 and 1991 general ilections). Pp. 55-72 in N. Arat. Turkiye'de Kadin Olamak. Istanbul: Say.

UNIFEM. Turning the Tide. New York: United Nations, 2001.

Wolf, Naomi. Hunger. Pp. 85-91 in A. Minas (ed.). Gender Basics (2nd ed.). Stamford, Connecticut: Wadsworth, 2000.

Zelditch, Morris Jr. Role differentiation in the nuclear family: A comparative study. In T. Parsons \& R.F. Bales (eds.). Family, Socialization \& Interaction Process. New York: Free Press, 1955. 